\title{
THE EFFECTS OF AN INCREASE IN PLASMA VOLUME ON THE METABOLISM AND EXCRETION OF WATER AND ELEC- TROLYTES BY NORMAL SUBJECTS ${ }^{1,2}$
}

\author{
By L. G. WELT 3 AND J. ORLOFF 4, 5 \\ (From the Department of Internal Medicine, Yale University School of Medicine, New Haven, \\ Conn.)
}

(Submitted for publication January 22, 1951 ; accepted April 23, 1951)

\section{INTRODUCTION}

Since the volume of body water is maintained within reasonable limits and the kidneys play a dominant role in this regulation, it is implicit that the existence of an abnormal volume is somehow transmitted to the kidney. In turn, some renal mechanism must be stimulated to alter the volume and composition of the urine in a manner that will tend to correct the abnormality. There may be volume receptors as such or the responsive mechanism may be stimulated by some function of an abnormal volume. The one compartment of body water whose volume is most readily altered by changes in the others and whose constancy is most important for a host of physiologic processes is the circulating plasma. It is, therefore, important to learn what alterations in renal function are associated with changes in plasma volume and in what manner these responses may be modified.

The volume of the plasma can be increased without alterations in the volumes of the other compartments of fluid by the infusion of a solution identical with plasma both with respect to filtrable constituents and colloid osmotic pressure. Solutions of gelatin, acacia, plasma, and albumin have been used therapeutically with success for this purpose. The infusion of a $25 \%$ or $10 \%$ solution of

1 Serum albumin used in this study was prepared by the American Red Cross from blood of volunteer donors. The conclusions are those of the authors and do not necessarily reflect the policy of the American Red Cross.

2 Aided by an institutional grant from the National Heart Institute, U. S. Public Health Service, and Contract V1001 M-1450 of the Veterans Administration.

${ }^{3}$ Work done in part during the tenure of a Post-doctorate Fellowship, U. S. Public Health Service.

4 Work done in part while a Fellow of the Dazian Foundation for Medical Research, and during the tenure of a Life Insurance Medical Research Fellowship.

5 Present address : National Heart Institute, U. S. Public Health Service, Bethesda, Md. albumin will expand the volume of the plasma at the expense of the interstitial fluid because such a solution is hyperoncotic with respect to the plasma of the recipient. Thus, by varying the concentration of the solution of albumin infused, an increase in plasma volume with or without a change in the interstitial fluid volume can be achieved.

Many investigators have studied this problem in the experimental animal and in man with conflicting results (1-5). This investigation is an attempt to study the alterations in the metabolism and excretion of electrolytes and water promoted by expansion of the plasma volume with hyper- and isooncotic solutions of purified salt-poor human albumin.

\section{EXPERIMENTAL PROCEDURE AND METHODS}

The experimental subjects in this study were two healthy physicians (J. O. and L. G. W.), one patient with well-controlled Addison's disease (R.N.), and four patients (B., B. B., S., and A.) with minor diseases unrelated to the cardiovascular-renal systems. Food and water were restricted for a period of 10 to 14 hours prior to each experiment except in L. G. W. 12-11-48 when fluids as such were restricted for 48 hours. Each experiment was conducted with the subject in the recumbent position, either on a couch or in bed, and was of six hours' duration except as indicated. The experiments were divided into three major periods : pre-infusion control, infusion, and post-infusion. All urines were voided specimens. Samples of blood were collected under oil at the end of each period.

All of the experiments except those noted in the tables as "evening studies" (L. G. W. 10-25-48 and J. 0. 2-1-49) were started at about 8 A.M. The "evening studies" were started at 6 P.M. after abstention from food and water for 10 hours.

No water was ingested during any of the studies where $4 \%, 5 \%, 6 \%$, and $10 \%$ solutions of albumin were infused, and in the experiments where $2,500 \mathrm{cc}$. of saline were infused prior to the administration of $25 \%$ saltpoor albumin. In all the other experiments in which a $25 \%$ solution of albumin was administered (except $\mathrm{L}$. G. W. 12-11-48) water was ingested at the rate of $100 \mathrm{cc}$. an hour. 
The control studies were designed to mimic the experiments under consideration in all details except for the protein in the infusion fluid. The concentration of sodium and chloride in $25 \%$ salt-poor human albumin is 157 and $20 \mathrm{mEq}$./L respectively, and the water content is approximately $80 \%$. The control infusion for $400 \mathrm{cc}$. of $25 \%$ saltpoor human albumin was, therefore, $325 \mathrm{cc}$. of an aqueous solution containing the same amount of sodium and chloride using appropriate amounts of $\mathrm{NaCl}$ and $\mathrm{NaHCO}_{3}$. The control infusion for $1,000 \mathrm{cc}$. of $10 \%$ albumin in saline was $1,000 \mathrm{cc}$. of normal saline. An equal volume of $5 \%$ glucose was used to control the experiment with $4 \%$ albumin in $5 \%$ glucose, and an equal volume of normal saline was used to control the studies with $4 \%, 5 \%$, and $6 \%$ albumin in normal saline. Water was ingested at the rate of $100 \mathrm{cc}$. an hour when this had prevailed in the experiment for which the control study was performed. In the other control studies no water was ingested.

The chemical methods and calculations have been described in previous publications from this department (69). In the calculations the value for the initial volume of extracellular fluid (chloride space) was assumed to be $20 \%$ of the body weight. The initial plasma volume was assumed to be $5 \%$ of the body weight. The value for total milli-osmols in the urine was calculated from the equation: $2(\mathrm{Na}+\mathrm{K})+$ urea. The percentage change in plasma volume, $\mathrm{PV}_{2} / \mathrm{PV}_{1}$, was calculated from the formula: $\frac{\mathrm{Hgb}_{1}}{\mathrm{Hgb}_{2}} \times \frac{1-\mathrm{Hkt}_{2}}{1-\mathrm{Hkt}_{1}} \times 100$.

In all the experiments, except L. G. W. 10-18 and $10-25-48$ and J. O. $10-20-48$, the concentration of creatinine in the serum was determined and the clearance of creatinine was calculated from the formula $\frac{U V}{S}$. In the three experiments, cited above, only the excretion of creatinine was determined and the concentration of creatinine in the serum was assumed to be constant at $1 \mathrm{mgm} . \%$ for the purpose of calculating the clearance of creatinine. Urea clearances were calculated from the formula, $\frac{U V}{B}$, regardless of the rate of urine flow.

\section{RESULTS}

The infusion of 50 or $100 \mathrm{gm}$. of a hyperoncotic solution $(25 \%$ or $10 \%)$ of albumin was invariably associated with an increase in the concentration and total circulating quantity of serum albumin and an enlarged plasma volume (Table I). There was a reciprocal fall in the concentration of serum globulin with a small and inconstant increase in total circulating globulin. Since there were no significant changes in the volume of the extracellular fluid, the increase in plasma volume was associated with a reciprocal fall in the volume of the interstitial fluid.
The calculated increase in total circulating albumin agreed quite closely with the quantity injected in six of nine studies. The discrepancies probably represent the compounding of errors inherent in the determinations involved. The percentage increase in plasma volume varied from $20 \%$ to $51 \%$, but was not necessarily related to the quantity of albumin injected. The increase in plasma volume per gram of albumin infused was greater when the protein was administered in less concentrated solutions (Tables I and II). The increase in plasma volume expressed as cubic centimeters per gram of albumin infused varied from 7.95 to 18.2 cc. with an average of $13.2 \mathrm{cc}$. when hyperoncotic solutions were infused, and from 10.2 to $28.8 \mathrm{cc}$. with an average of $18.9 \mathrm{cc}$. when hypo- or isooncotic solutions were administered. Infusions of hyperoncotic solutions of albumin after prior expansion of the extracellular space with $2 \frac{1}{2}$ liters of normal saline were associated with an increase in plasma volume of $11.6 \mathrm{cc}$. per gm. There were no consistent significant changes in the size of the red cells as indicated by the values for $\mathrm{Hgb} / \mathrm{Hkt}$.

Infusions of hyperoncotic ( $25 \%$ or $10 \%)$ solutions of albumin in the experiments conducted in the morning (Table III) were associated with no consistent change in the clearance of endogenous creatinine. The infusions were associated with no change or a fall in the rates of excretion of sodium and chloride when compared to the preinfusion control periods. There were no instances where the rate of excretion of either of these two ions was augmented. In contrast, in the control study for L. G. W. 10-18-48, where the infusion had the same volume of water and content of sodium and chloride as the $25 \%$ solution of albumin, the rates of excretion of sodium and chloride were distinctly increased. This same difference in the response to a non-colloid solution of equal volume and salt content as compared to an infusion of a $10 \%$ solution of albumin in normal saline is evident by inspecting the results in experiment $\mathrm{J}$. $\mathrm{O}$. 1-8-49 and its control (Table III).

It is more difficult to analyze the response in the rate of excretion of water associated with the administration of a $25 \%$ solution of albumin, since in all but one of these studies water was ingested at a rate of $100 \mathrm{cc}$. $/ \mathrm{hr}$., which would be expected to increase the rate of flow of urine. In the experiment 
TABLE I

The effect of hyperoncotic solutions of albumin on the serum proteins and the volumes of the plasma and interstitial fluids

\begin{tabular}{|c|c|c|c|c|c|c|c|c|c|c|c|c|c|c|}
\hline \multirow{2}{*}{ Study } & \multirow{2}{*}{ Period } & \multirow{2}{*}{$\underset{\text { tion }}{\text { Dura- }}$} & \multirow{2}{*}{$\begin{array}{c}\text { Intra- } \\
\text { venous } \\
\text { albumin }\end{array}$} & \multicolumn{3}{|c|}{ Conc. in serum } & \multirow{2}{*}{ Hkt } & \multirow{2}{*}{ Hgb } & \multirow{2}{*}{$\frac{\mathrm{Hgb}}{\mathrm{Hkt}}$} & \multirow{2}{*}{$\frac{\mathrm{PV}_{2}}{\mathrm{PV}_{1}}$} & \multirow{2}{*}{$\begin{array}{l}\triangle \mathrm{PV} \\
\text { per gm. } \\
\text { albumin }\end{array}$} & \multirow{2}{*}{$\begin{array}{l}\Delta \text { Total } \\
\text { circul. } \\
\text { albumin }\end{array}$} & \multirow{2}{*}{$\begin{array}{l}\Delta \text { Total } \\
\text { circul. } \\
\text { globulin }\end{array}$} & \multirow{2}{*}{ IFV } \\
\hline & & & & $\begin{array}{c}\text { Total } \\
\text { protein }\end{array}$ & $\begin{array}{l}\text { Albu- } \\
\text { min }\end{array}$ & 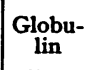 & & & & & & & & \\
\hline $\begin{array}{c}\text { L. G. W. } \\
10-11-48 \\
25 \%\end{array}$ & $\begin{array}{c}\text { I } \\
\text { II } \\
\text { III } \\
\text { IV }\end{array}$ & $\begin{array}{c}\text { min. } \\
118 \\
60^{*} \\
60 \\
60\end{array}$ & $\begin{array}{l}8 m . \\
50\end{array}$ & $\begin{array}{c}g m . \% \\
6.40 \\
7.24 \\
7.21 \\
7.21\end{array}$ & \begin{tabular}{|c|}
$g m . \%$ \\
4.15 \\
5.17 \\
5.06 \\
4.90
\end{tabular} & \begin{tabular}{|l|}
$g m . \%$ \\
2.25 \\
2.07 \\
2.15 \\
2.31
\end{tabular} & \begin{tabular}{|c|}
$00 l . \%$ \\
46.0 \\
40.4 \\
38.6 \\
40.1
\end{tabular} & \begin{tabular}{|l|}
$g m . \%$ \\
15.1 \\
13.6 \\
13.8 \\
13.6
\end{tabular} & $\begin{array}{l}32.8 \\
33.7 \\
35.8 \\
33.9\end{array}$ & $\begin{array}{c}\% \\
100 \\
123 \\
124 \\
123\end{array}$ & 18.2 & 87.2 & $\begin{array}{l}g m . \\
10 .\end{array}$ & $\begin{array}{l}\text { liters } \\
-0.870 \\
-1.110 \\
-0.760\end{array}$ \\
\hline$\underset{10-18-48}{\text { L. G. W. }}$ & I & $\begin{array}{c}120 \\
57^{*}\end{array}$ & 50 & 6.87 & 4.45 & 2.42 & 45.2 & 14.7 & 39.4 & 100 & & & & \\
\hline $25 \%$ & III & $\begin{array}{l}78^{*} \\
120\end{array}$ & 50 & $\begin{array}{l}7.91 \\
7.62\end{array}$ & $\begin{array}{l}5.94 \\
5.76\end{array}$ & $\begin{array}{l}1.97 \\
1.86\end{array}$ & $\begin{array}{l}42.0 \\
40.5\end{array}$ & $\begin{array}{l}13.0 \\
13.1\end{array}$ & $\begin{array}{l}37.9 \\
39.5\end{array}$ & $\begin{array}{l}120 \\
122\end{array}$ & 7.95 & 106.5 & -2.2 & $\begin{array}{l}-0.475 \\
-0.790\end{array}$ \\
\hline$\underset{10-25-48}{\text { L. G. W. }}$ & I & $\begin{array}{c}120 \\
59^{*}\end{array}$ & 50 & 7.07 & 4.52 & 2.55 & 42.0 & 13.8 & 32.9 & 100 & & & & \\
\hline$\underset{25 \%}{\text { Evening study }}$ & III & $\begin{array}{l}61^{*} \\
120\end{array}$ & 50 & $\begin{array}{l}8.20 \\
7.70\end{array}$ & $\begin{array}{l}6.10 \\
5.82\end{array}$ & $\begin{array}{l}2.10 \\
1.88\end{array}$ & $\begin{array}{l}37.0 \\
38.7\end{array}$ & $\begin{array}{l}12.0 \\
12.6\end{array}$ & $\begin{array}{l}32.5 \\
32.6\end{array}$ & $\begin{array}{l}125 \\
115\end{array}$ & 10.0 & 126.5 & 3.2 & $\begin{array}{l}-0.890 \\
-0.930\end{array}$ \\
\hline L. G. W. & I & $\begin{array}{c}120 \\
60^{*}\end{array}$ & 50 & 7.43 & 4.27 & 3.16 & 46.3 & 15.6 & 33.7 & 100 & & & & \\
\hline $\begin{array}{l}\text { Dehydrated } \\
25 \%\end{array}$ & IIV & $\begin{array}{l}60^{*} \\
120\end{array}$ & 50 & $\begin{array}{l}8.45 \\
8.15\end{array}$ & $\begin{array}{l}6.29 \\
5.92\end{array}$ & $\begin{array}{l}2.16 \\
2.23\end{array}$ & $\begin{array}{l}38.7 \\
40.5\end{array}$ & $\begin{array}{l}12.8 \\
12.8\end{array}$ & $\begin{array}{l}33.1 \\
31.6\end{array}$ & $\begin{array}{l}139 \\
135\end{array}$ & 15.3 & 175 & -6.3 & $\begin{array}{l}-1.38 \\
-1.19\end{array}$ \\
\hline$\underset{10-15-48}{\mathrm{~J} . \mathrm{O}}$ & $\begin{array}{l}\text { II } \\
\text { III }\end{array}$ & $\begin{array}{c}120 \\
60^{*} \\
60\end{array}$ & 50 & $\begin{array}{l}6.86 \\
7.06\end{array}$ & $\begin{array}{l}4.59 \\
5.15\end{array}$ & $\begin{array}{l}2.26 \\
1.91\end{array}$ & $\begin{array}{l}41.9 \\
37.6\end{array}$ & $\begin{array}{l}13.8 \\
12.1\end{array}$ & $\begin{array}{l}32.9 \\
32.2\end{array}$ & $\begin{array}{l}100 \\
122\end{array}$ & 15.0 & 59.6 & 2.5 & -0.885 \\
\hline & IV & 60 & & 7.17 & 5.17 & 2.00 & 34.9 & 12.4 & 35.5 & 125 & & & & \\
\hline${ }_{10-20-48}^{\mathrm{J}} .{ }^{\circ}$ & I & $\begin{array}{c}120 \\
63^{*}\end{array}$ & 50 & 6.81 & 4.61 & 2.20 & 39.6 & 13.5 & 34.1 & 100 & & & & \\
\hline $25 \%$ & III & $\begin{array}{l}58^{*} \\
120\end{array}$ & 50 & $\begin{array}{l}8.24 \\
8.17\end{array}$ & $\begin{array}{l}6.23 \\
6.06\end{array}$ & $\begin{array}{l}2.01 \\
2.11\end{array}$ & $\begin{array}{l}35.6 \\
36.7\end{array}$ & $\begin{array}{l}11.7 \\
12.3\end{array}$ & $\begin{array}{l}32.9 \\
33.5\end{array}$ & $\begin{array}{l}123 \\
115\end{array}$ & 8.1 & 108 & 9.7 & $\begin{array}{l}-1.03 \\
-1.12\end{array}$ \\
\hline$\underset{1-8-48}{\mathrm{~J}} \underset{1-}{O}$ & I & $\begin{array}{c}120 \\
60^{*}\end{array}$ & 50 & 6.75 & 4.35 & 2.40 & 44.9 & 13.8 & 30.7 & 100 & & & & \\
\hline $10 \%$ & III & $\begin{array}{l}60^{*} \\
120\end{array}$ & 50 & $\begin{array}{l}7.46 \\
7.46\end{array}$ & $\begin{array}{l}5.34 \\
5.40\end{array}$ & $\begin{array}{l}2.12 \\
2.06\end{array}$ & $\begin{array}{l}35.7 \\
38.8\end{array}$ & $\begin{array}{l}11.4 \\
12.0\end{array}$ & $\begin{array}{l}31.8 \\
30.9\end{array}$ & $\begin{array}{l}142 \\
128\end{array}$ & 15.7 & 121 & 22.7 & $\begin{array}{l}-1.04 \\
-0.52\end{array}$ \\
\hline$\underset{2-1-49}{\mathrm{~J} \cdot O}$ & $\underset{\text { II }}{\text { I }}$ & $\begin{array}{c}120 \\
60^{*}\end{array}$ & 50 & 7.58 & 4.77 & 2.81 & 41.8 & 13.2 & 31.6 & 100 & & & & \\
\hline $\begin{array}{c}\text { Evening study } \\
25 \%\end{array}$ & III & $\begin{array}{l}60^{*} \\
120\end{array}$ & 50 & $\begin{array}{l}7.97 \\
7.82\end{array}$ & $\begin{array}{l}5.89 \\
5.95\end{array}$ & $\begin{array}{l}2.08 \\
1.87\end{array}$ & $\begin{array}{l}35.6 \\
38.0\end{array}$ & $\begin{array}{l}10.9 \\
11.8\end{array}$ & \begin{tabular}{|l|}
30.6 \\
31.1
\end{tabular} & $\begin{array}{l}134 \\
119\end{array}$ & 12.2 & 111.8 & -1 & $\begin{array}{l}-1.110 \\
-0.630\end{array}$ \\
\hline$\underset{1-13-49}{R . N .}$ & I & $\begin{array}{c}120 \\
60^{*}\end{array}$ & 50 & 7.64 & 3.77 & 3.87 & 40.4 & 12.2 & 30.2 & 100 & & & & \\
\hline $25 \%$ & III & $\begin{array}{c}60^{*} \\
120\end{array}$ & 50 & $\begin{array}{l}8.08 \\
7.79\end{array}$ & $\begin{array}{l}4.95 \\
5.18\end{array}$ & $\begin{array}{l}3.13 \\
2.61\end{array}$ & $\begin{array}{l}30.7 \\
35.3\end{array}$ & $\begin{array}{l}9.4 \\
9.8\end{array}$ & $\begin{array}{l}30.4 \\
27.8\end{array}$ & $\begin{array}{l}151 \\
135\end{array}$ & 16.6 & 121 & 28 & $\begin{array}{l}-1.91 \\
-1.32\end{array}$ \\
\hline
\end{tabular}

* Period of infusion.

L. G. W. 10-18 and its control (Table III) the rates of excretion of water do not differ significantly. In the one study where a $25 \%$ solution of albumin was injected and no water was taken by mouth (L. G. W. 12-11-48) there was a decrease in the rate of excretion of water in the postinfusion period. Comparison of the rates of excretion of water in the experiments J. O. 1-8-49 and its control reveals that the hyperoncotic solution of albumin (10\%) provoked a mild antidiuretic response. It should be noted, however, that this antidiuresis was associated with a decrease in the concentration of total milliosmols in the urine. These responses with respect to the rates of excretion of sodium and water associated with infusions of hyperoncotic solutions of albumin in normal subjects are in striking contrast to the responses in patients with the nephrotic syndrome and toxemias of pregnancy (10-13).

Two subjects (Table IV) were given an infusion of $100 \mathrm{cc}$. $(50 \mathrm{gm}$.) of $25 \%$ albumin after the extracellular space had been expanded with 
2,500 cc. of normal saline. These studies were controlled by the administration of $200 \mathrm{cc}$. of normal saline in lieu of the albumin solution after the initial expansion of the extracellular space. Despite prior expansion of the volume of extracellular fluid, the infusion of a solution of $25 \%$ albumin did not promote an increase in the rates of excretion of sodium or water. On the contrary, the albumin infusion clearly retarded the rate of excretion of sodium, chloride, potassium, and water in subject B. B.

Infusions of hyperoncotic solutions of albumin at night were associated with a somewhat different response than those observed during the morning (Table V). The rates of excretion of sodium and chloride in the control period are distinctly lower than they were in the comparable period in the morning. The infusion of $100 \mathrm{gm}$. of $25 \%$ albumin in both subjects and the control infusion were each followed by a slight increase in the rate of excretion of sodium and a decrease in the rates of excretion of both chloride and potassium. Examination of the rates of excretion of water in experiment J. O. 2-1-49 and its control reveals no significant difference.

The responses provoked by infusions of isoand hypo-oncotic solutions of albumin are in striking contrast to the foregoing (Table VI). Infusions of $2,280 \mathrm{cc}$. of $4 \%, 5 \%$, and $6 \%$ solutions of albumin in saline, and $1,825 \mathrm{cc}$. of a $4 \%$ solution of albumin in $5 \%$ glucose promote a striking increase in the rate of excretion of water. This di-

TABLE II

The effect of hypo-and iso-oncotic solutions of albumin on the serum proteins and the volumes of the plasma and interstitial fluid.

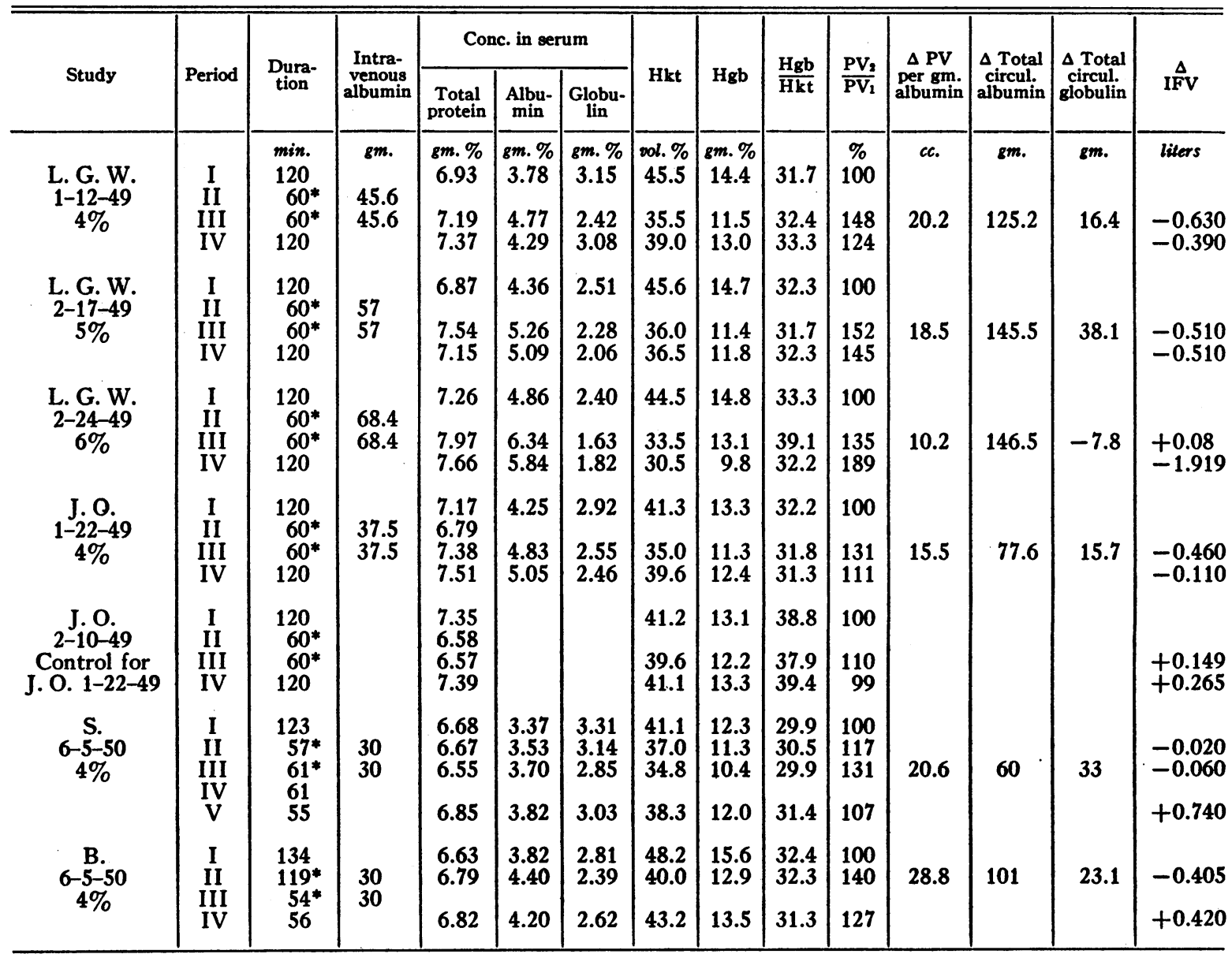

* Period of infusion. 
TABLE III

The effect of infusion of hyperoncotic solutions of albumin on the concentrations of extracellular electrolytes, clearances, and rates of excretion of water and solutes in the urine

\begin{tabular}{|c|c|c|c|c|c|c|c|c|c|c|c|c|c|}
\hline \multirow[b]{2}{*}{ Study } & \multirow[b]{2}{*}{ Period } & \multirow{2}{*}{$\begin{array}{c}\text { Dura- } \\
\text { tion }\end{array}$} & \multicolumn{3}{|c|}{ Extracell. $\mathrm{H}_{2} \mathrm{O}$} & \multicolumn{6}{|c|}{ Rates of excretion in urine } & \multicolumn{2}{|c|}{ Clearances } \\
\hline & & & $\mathrm{Na}$ & $\mathrm{Cl}$ & $\mathbf{K}$ & $\mathrm{H}_{2} \mathrm{O}$ & $\mathbf{N a}$ & $\mathrm{Cl}$ & $\mathbf{k}$ & Urea & $\begin{array}{c}\text { Total } \\
\text { mOsm. }\end{array}$ & Creatin. & Urea \\
\hline $\begin{array}{c}\text { L. G. W. } \\
10-11-48 \\
25 \%-50 \mathrm{gm} .\end{array}$ & $\begin{array}{l}\text { I } \\
\text { III } \\
\text { IV }\end{array}$ & $\begin{array}{c}\min . \\
118 \\
60^{*} \\
60 \\
60\end{array}$ & $m E q / L$ & $\begin{array}{c}E q / L \\
115 \\
113 \\
114 \\
111\end{array}$ & $m E q / L$ & $\begin{array}{r}c c . / 1^{\circ} \\
92.4 \\
130.0 \\
352.0 \\
65.0\end{array}$ & $\begin{array}{c}m E q / 1^{\circ} \\
12.6 \\
14.5 \\
12.7 \\
13.2\end{array}$ & $\begin{array}{c}m E q / 1^{\circ} \\
14.4 \\
13.4 \\
13.1 \\
15.1\end{array}$ & \begin{tabular}{|c|}
$m E q / 1^{\circ}$ \\
4.5 \\
2.3 \\
2.6 \\
3.8
\end{tabular} & $\overline{m M / 1^{\circ}}$ & $\overline{m M / 1^{\circ}}$ & $\overline{c c . / m i n}$. & $\overline{c c . / \min .}$ \\
\hline $\begin{array}{c}\text { L. G. W. } \\
10-18-48 \\
25 \%-100 \mathrm{gm} .\end{array}$ & $\begin{array}{l}\text { I } \\
\text { II } \\
\text { III } \\
\text { IV }\end{array}$ & $\begin{array}{c}120 \\
57^{*} \\
78^{*} \\
120\end{array}$ & $\begin{array}{l}146 \\
146 \\
145\end{array}$ & $\begin{array}{l}115 \\
111 \\
111\end{array}$ & & \begin{tabular}{|l|}
201.5 \\
405 \\
169.2 \\
141
\end{tabular} & $\begin{array}{l}17.4 \\
18.7 \\
15.2 \\
17.8\end{array}$ & $\begin{array}{l}19.6 \\
18.5 \\
12.7 \\
18.6\end{array}$ & $\begin{array}{l}4.3 \\
5.8 \\
5.1 \\
2.5\end{array}$ & $\begin{array}{l}20.7 \\
19.5 \\
15.6 \\
16.5\end{array}$ & $\begin{array}{l}64.1 \\
68.5 \\
56.2 \\
57.1\end{array}$ & $\begin{array}{l}126 \\
107 \\
124 \\
113\end{array}$ & $\begin{array}{l}87.3 \\
82.0 \\
68.0 \\
75.0\end{array}$ \\
\hline $\begin{array}{l}\text { L. G. W. } \\
\text { Control for } \\
10-18-48\end{array}$ & $\begin{array}{l}\text { I } \\
\text { II } \\
\text { III } \\
\text { IV }\end{array}$ & $\begin{array}{c}120 \\
60^{*} \\
60^{*} \\
120\end{array}$ & & & & $\begin{array}{l}140 \\
380 \\
135 \\
182\end{array}$ & $\begin{array}{r}7.3 \\
15.9 \\
15.9 \\
10.9\end{array}$ & $\begin{array}{l}10.4 \\
20.5 \\
16.4 \\
11.3\end{array}$ & & & & & \\
\hline $\begin{array}{c}\text { L. G. W. } \\
12-11-48 \\
25 \%-100 \mathrm{gm} . \\
\text { Dehydrated }\end{array}$ & $\begin{array}{l}\text { I } \\
\text { III } \\
\text { IV }\end{array}$ & $\begin{array}{c}120 \\
60^{*} \\
60^{*} \\
120\end{array}$ & $\begin{array}{l}148 \\
150 \\
149\end{array}$ & $\begin{array}{l}117 \\
116 \\
115\end{array}$ & $\begin{array}{l}4.6 \\
4.2 \\
4.2\end{array}$ & $\begin{array}{l}49.5 \\
58 \\
51 \\
28.5\end{array}$ & $\begin{array}{r}12.6 \\
12.9 \\
9.5 \\
3.4\end{array}$ & $\begin{array}{r}12.0 \\
9.8 \\
6.3 \\
4.6\end{array}$ & $\begin{array}{l}4.4 \\
6.3 \\
6.4 \\
3.8\end{array}$ & & & \begin{tabular}{|l|}
116.9 \\
106.1 \\
102.5 \\
107.0
\end{tabular} & \\
\hline $\begin{array}{c}\text { J. O. } \\
10-15-48 \\
25 \%-50 \mathrm{gm} .\end{array}$ & $\begin{array}{l}\text { I } \\
\text { III } \\
\text { IV }\end{array}$ & $\begin{array}{c}120 \\
60^{*} \\
60 \\
60\end{array}$ & $\begin{array}{l}144 \\
147 \\
144\end{array}$ & $\begin{array}{l}115 \\
115 \\
113\end{array}$ & & $\begin{array}{r}66 \\
90 . \\
205 \\
158\end{array}$ & $\begin{array}{l}15.2 \\
15.3 \\
10.7 \\
16.1\end{array}$ & $\begin{array}{l}15.2 \\
14.4 \\
10.5 \\
16.6\end{array}$ & $\begin{array}{l}4.0 \\
6.9 \\
4.7 \\
1.7\end{array}$ & & & & \\
\hline $\begin{array}{c}\mathrm{J} . O . \\
10-20-48 \\
25 \%-100 \mathrm{gm} .\end{array}$ & $\begin{array}{l}\text { I } \\
\text { II } \\
\text { III } \\
\text { IV }\end{array}$ & $\begin{array}{c}120 \\
63^{*} \\
58^{*} \\
120\end{array}$ & $\begin{array}{l}141 \\
143 \\
144\end{array}$ & $\begin{array}{l}111 \\
112 \\
113\end{array}$ & & $\begin{array}{l}150 \\
161.4 \\
289.2 \\
292.5\end{array}$ & $\begin{array}{r}11.1 \\
13.1 \\
6.3 \\
7.1\end{array}$ & $\begin{array}{r}15.4 \\
13.9 \\
5.1 \\
4.9\end{array}$ & $\begin{array}{r}9.9 \\
11.4 \\
6.7 \\
3.1\end{array}$ & $\begin{array}{l}22.2 \\
21.4 \\
15.4 \\
16.1\end{array}$ & $\begin{array}{l}64.2 \\
70.4 \\
41.4 \\
36.5\end{array}$ & $\begin{array}{r}132 \\
123 \\
94 \\
112\end{array}$ & \begin{tabular}{|l|}
67.8 \\
65.4 \\
48.7 \\
50.8
\end{tabular} \\
\hline $\begin{array}{c}\mathrm{J} . O . \\
1-8-49 \\
10 \%-100 \mathrm{gm} .\end{array}$ & $\begin{array}{l}\text { I } \\
\text { II } \\
\text { IV }\end{array}$ & $\begin{array}{c}120 \\
60^{*} \\
60^{*} \\
120\end{array}$ & $\begin{array}{l}142 \\
144 \\
145\end{array}$ & $\begin{array}{l}116 \\
118 \\
116\end{array}$ & $\begin{array}{l}4.2 \\
4.2 \\
4.2\end{array}$ & $\begin{array}{l}61 \\
78 \\
50 \\
49\end{array}$ & $\begin{array}{r}11.6 \\
8.5 \\
6.5 \\
10.3\end{array}$ & $\begin{array}{r}14.6 \\
11.1 \\
6.8 \\
9.9\end{array}$ & $\begin{array}{r}7.0 \\
12.1 \\
7.0 \\
3.0\end{array}$ & $\begin{array}{l}17.6 \\
15.8 \\
13.9 \\
14.3\end{array}$ & $\begin{array}{l}54.8 \\
57.0 \\
40.9 \\
40.9\end{array}$ & $\begin{array}{l}132.1 \\
121.2 \\
124.2 \\
125.0\end{array}$ & \begin{tabular}{|l|}
58.5 \\
54.7 \\
48.3 \\
49.8
\end{tabular} \\
\hline $\begin{array}{c}\text { J. O. } \\
\text { Control for } \\
1-8-49\end{array}$ & $\begin{array}{l}\text { I } \\
\text { II } \\
\text { IV }\end{array}$ & $\begin{array}{c}120 \\
60^{*} \\
60^{*} \\
120\end{array}$ & & & & $\begin{array}{r}58 \\
94 \\
126 \\
145\end{array}$ & $\begin{array}{l}11.3 \\
19.6 \\
25.0 \\
29.3\end{array}$ & $\begin{array}{l}13.1 \\
2.05 \\
26.3 \\
29.2\end{array}$ & & & & & \\
\hline $\begin{array}{c}\text { R. N. } \\
1-13-49 \\
25 \%-100 \mathrm{gm} .\end{array}$ & $\begin{array}{l}\text { I } \\
\text { II } \\
\text { III } \\
\text { IV }\end{array}$ & $\begin{array}{c}120 \\
60^{*} \\
60^{*} \\
120\end{array}$ & $\begin{array}{l}143 \\
142 \\
143\end{array}$ & $\begin{array}{l}109 \\
110 \\
108\end{array}$ & $\begin{array}{l}3.8 \\
3.6 \\
3.7\end{array}$ & $\begin{array}{l}95 \\
97 \\
70 \\
71\end{array}$ & $\begin{array}{r}17.8 \\
16.2 \\
7.2 \\
9.1\end{array}$ & $\begin{array}{r}16.8 \\
14.6 \\
6.6 \\
7.9\end{array}$ & $\begin{array}{l}6.1 \\
6.9 \\
7.6 \\
5.6\end{array}$ & $\begin{array}{l}13.1 \\
13.2 \\
10.9 \\
11.1\end{array}$ & $\begin{array}{l}60.9 \\
59.4 \\
40.5 \\
40.5\end{array}$ & $\begin{array}{l}108.5 \\
110.5 \\
102.3 \\
102.5\end{array}$ & $\begin{array}{l}39.4 \\
39.6 \\
38.8 \\
39.1\end{array}$ \\
\hline
\end{tabular}

* Period of infusion.

uresis of water occurred during the second hour of the infusion period and was always distinctly larger than the rate of excretion of water in the comparable period of the control study. This diuresis was not associated with a significant increase in the clearance of endogenous creatinine. Although the rates of excretion of sodium and chloride are also increased, they do not differ significantly from the rates of excretion of these ions in comparable periods of the control studies. The rate of excretion of potassium was increased when saline was the diluent for the albumin. The diuresis of water was not dependent on a decrease in the concentration of sodium in the extracellular water since it occurred with both $5 \%$ glucose and normal saline as the diluent.

In the post-infusion period there was a decrease in the rate of excretion of water and salt. This may be related to the fact that the large loss of water in the urine causes an increase in the concen- 
TABLE IV

The effect of infusion of hyperoncotic solutions of albumin on the concentrations of extracellular electrolytes, clearances, and rates of excretion of water and solutes in the urine in normal subjects with expanded extracellular volumes

\begin{tabular}{|c|c|c|c|c|c|c|c|c|c|c|}
\hline \multirow{2}{*}{ Study } & \multirow{2}{*}{ Period } & \multirow{2}{*}{ Duration } & \multicolumn{3}{|c|}{ Conc. in extracell. $\mathrm{H}_{2} \mathrm{O}$} & \multicolumn{4}{|c|}{ Rates of excretion in urine } & \multirow{2}{*}{$\begin{array}{l}\text { Clearance } \\
\text { Creatinine }\end{array}$} \\
\hline & & & $\mathrm{Na}$ & $\mathrm{Cl}$ & $\mathrm{K}$ & $\mathrm{H}_{2} \mathrm{O}$ & $\mathrm{Na}$ & $\mathrm{Cl}$ & $\mathbf{K}$ & \\
\hline $\begin{array}{c}\text { B. B. } \\
2-13-50 \\
25 \%-50 \mathrm{gm} .\end{array}$ & $\begin{array}{l}\text { I } \\
\text { II } \\
\text { III } \\
\text { IV } \\
\text { V }\end{array}$ & $\begin{array}{l}\min . \\
249 \\
116^{*} \\
89 \dagger \\
72 \\
88\end{array}$ & $\begin{array}{c}m E q / L \\
145 \\
148 \\
147 \\
148 \\
146\end{array}$ & $\begin{array}{c}m E q / L \\
118 \\
120 \\
120 \\
120 \\
117\end{array}$ & $\begin{array}{c}m E q / L \\
3.9 \\
3.9 \\
3.5 \\
3.8 \\
3.6\end{array}$ & $\begin{array}{l}c c . / 1^{\circ} \\
60.7 \\
196.6 \\
357 \\
210 \\
112.5\end{array}$ & $\begin{array}{c}m E q / 1^{\circ} \\
17.3 \\
43.3 \\
63.9 \\
37.3 \\
26.4\end{array}$ & $\begin{array}{c}m E q / 1^{\circ} \\
15.6 \\
42.7 \\
60.8 \\
35.9 \\
25.7\end{array}$ & $\begin{array}{c}m E q / 1^{\circ} \\
3.0 \\
3.2 \\
4.8 \\
2.8 \\
2.5\end{array}$ & $\begin{array}{c}c c . / m i n . \\
99 \\
93.6 \\
97.8 \\
86 \\
102\end{array}$ \\
\hline $\begin{array}{l}\text { B. B. } \\
\text { Control for } \\
2-13-50\end{array}$ & $\begin{array}{l}\text { I } \\
\text { II } \\
\text { III } \\
\text { IV } \\
\text { V }\end{array}$ & $\begin{array}{c}253 \\
123 * \\
52 \ddagger \\
60 \\
109\end{array}$ & & & & $\begin{array}{l}37.5 \\
155 \\
397 \\
525 \\
161.8\end{array}$ & $\begin{array}{l}10.9 \\
27.9 \\
54.5 \\
76.6 \\
33.2\end{array}$ & $\begin{array}{l}9.3 \\
27.3 \\
53 \\
77.2 \\
33.5\end{array}$ & $\begin{array}{l}2.4 \\
2.7 \\
4.8 \\
8.1 \\
3.7\end{array}$ & \\
\hline $\begin{array}{c}\text { A. } \\
12-14-49 \\
25 \%-50 \mathrm{gm} .\end{array}$ & $\begin{array}{l}\text { I } \\
\text { II } \\
\text { III } \\
\text { IV } \\
\text { V }\end{array}$ & $\begin{array}{c}62 \\
117^{*} \\
56 \dagger \\
63 \\
118\end{array}$ & $\begin{array}{l}147 \\
148 \\
146 \\
147 \\
145\end{array}$ & $\begin{array}{l}114 \\
117 \\
115 \\
118 \\
115\end{array}$ & $\begin{array}{l}4.3 \\
4.0 \\
3.8 \\
4.0 \\
3.8\end{array}$ & $\begin{array}{r}91.8 \\
74.4 \\
128.8 \\
123.9 \\
92.6\end{array}$ & $\begin{array}{l}10.5 \\
12.1 \\
21.8 \\
20.8 \\
16.4\end{array}$ & $\begin{array}{l}12.7 \\
11.7 \\
21.0 \\
19.2 \\
16.5\end{array}$ & $\begin{array}{l}6.5 \\
3.4 \\
4.2 \\
3.6 \\
2.5\end{array}$ & $\begin{array}{c}163 \\
105.3 \\
100 \\
97.2 \\
97.4\end{array}$ \\
\hline $\begin{array}{c}\text { A. } \\
\text { Control for } \\
12-14-49\end{array}$ & $\begin{array}{l}\text { I } \\
\text { II } \\
\text { III } \\
\text { IV } \\
\text { V }\end{array}$ & $\begin{array}{c}68 \\
119^{*} \\
54 \ddagger \\
68 \\
119\end{array}$ & & & & $\begin{array}{l}68 \\
88.2 \\
138.6 \\
113 \\
100.9\end{array}$ & $\begin{array}{l}10.4 \\
17.8 \\
31.8 \\
27.9 \\
27.2\end{array}$ & $\begin{array}{l}14.2 \\
20.6 \\
32.2 \\
27.5 \\
25.5\end{array}$ & $\begin{array}{l}5.7 \\
4.5 \\
3.6 \\
2.8 \\
2.6\end{array}$ & \\
\hline
\end{tabular}

* Period of infusion of $2,500 \mathrm{cc}$. normal saline.

t Period of infusion of $200 \mathrm{cc} .25 \%$ albumin.

$\ddagger$ Period of infusion of $200 \mathrm{cc}$. normal saline.

tration of proteins in the serum similar to that observed with infusions of hyperoncotic solutions of albumin.

Infusions of $1,500 \mathrm{cc}$. of a $4 \%$ solution of albumin in saline containing 200 milli-units of a posterior pituitary preparation were unassociated with a diuresis of water, or any significant alteration in the rate of excretion of sodium, chloride, or potassium (Table VII).

\section{DISCUSSION}

A review of the previous investigations on the alterations induced in the composition and rate of flow of urine promoted by increasing the volume of the plasma reveals many seemingly conflicting results. Knowlton (1) and Podhradszky (14) reported a diminished rate of flow of urine with infusions of solutions of colloid in contrast to saline in rabbits and dogs. However, Metcalf (15) and Orloff and Blake (16) reported an increase in the rate of excretion of water in dogs in response to infusions of plasma and concentrated human serum albumin.
Reports of the responses of the normal human subject to infusions of $25 \%$ salt-poor human albu$\mathrm{min}$ are also at variance. Goodyer, Peterson, and Relman (17) observed a reduction in the rate of excretion of water, sodium, and chloride with no significant change in the clearance of mannitol. More recently, Elkinton and his associates (2) described an increased rate of excretion of sodium in normal subjects with similar infusions. They also found no changes in the rate of glomerular filtration as measured by the clearance of mannitol, inulin, or endogenous creatinine. Cargill (3) infused normal hypertensive and nephritic subjects rapidly with $25 \%$ albumin and reported an increase in the clearance of inulin and PAH. It is impossible, at this time, to reconcile these conflicting results.

There may be less variability in the reported responses to iso-oncotic expansion of the plasma volume. Eggleton, Pappenheimer and Winton (4) compared the diuretic response in anesthetized dogs to an increase of glomerular filtration brought about by a $5 \mathrm{~mm}$. $\mathrm{Hg}$ increase in capillary pressure, 
TABLE V

The effect of infusion of hyperoncotic solutions of albumin at night on the concentrations of extracellular electrolytes, clearances, and rates of excretion of water and solutes in the urine

\begin{tabular}{|c|c|c|c|c|c|c|c|c|c|c|c|c|c|}
\hline \multirow{2}{*}{ Study } & \multirow{2}{*}{ Period } & \multirow{2}{*}{$\underset{\text { tion }}{\text { Dura- }}$} & \multicolumn{3}{|c|}{ Conc. in extracell. $\mathrm{H}_{2} \mathrm{O}$} & \multicolumn{6}{|c|}{ Rates of excretion in urine } & \multicolumn{2}{|c|}{ Clearances } \\
\hline & & & $\mathrm{Na}$ & $\mathrm{Cl}$ & $\mathbf{K}$ & $\mathrm{H}_{2} \mathrm{O}$ & $\mathrm{Na}$ & $\mathrm{Cl}$ & $\mathbf{K}$ & Urea & $\begin{array}{c}\text { Total } \\
\text { mOsm. }\end{array}$ & Creatin. & Urea \\
\hline $\begin{array}{c}\text { L. G. W. } \\
10-25-48 \\
25 \%-100 \mathrm{gm} .\end{array}$ & $\begin{array}{l}\text { II } \\
\text { III } \\
\text { IV }\end{array}$. & $\begin{array}{c}\min . \\
120 \\
59^{*} \\
61^{*} \\
120\end{array}$ & $\begin{array}{c}m E q / L \\
143 \\
\\
144 \\
142\end{array}$ & $\begin{array}{c}m E q / L \\
112 \\
111 \\
113\end{array}$ & $m E q / L$ & $\begin{array}{c}c c . / 1^{\circ} \\
58 \\
60 \\
336 \\
221\end{array}$ & $\begin{array}{c}m E q / 1^{\circ} \\
4.4 \\
5.9 \\
6.4 \\
4.9\end{array}$ & $\begin{array}{c}\dot{m} E q / 1^{\circ} \\
4.3 \\
2.8 \\
2.1 \\
3.5\end{array}$ & $\begin{array}{c}m E q / 1^{\circ} \\
1.9 \\
2.3 \\
5.4 \\
2.6\end{array}$ & $\begin{array}{c}m M / 1^{\circ} \\
15.1 \\
15.1 \\
18.0 \\
16.6\end{array}$ & $\begin{array}{c}m M / 1^{\circ} \\
27.7 \\
31.5 \\
41.6 \\
31.6\end{array}$ & $\begin{array}{c}c c . / m i n \\
121 \\
122 \\
120 \\
106\end{array}$ & $\begin{array}{c}c c . / \min . \\
52.5 \\
52.6 \\
60.3 \\
57.6\end{array}$ \\
\hline 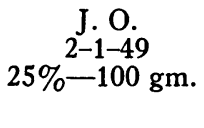 & $\begin{array}{l}\text { I } \\
\text { II } \\
\text { III } \\
\text { IV }\end{array}$ & $\begin{array}{c}120 \\
60^{*} \\
60^{*} \\
120\end{array}$ & $\begin{array}{l}146 \\
145 \\
144\end{array}$ & $\begin{array}{l}112 \\
111 \\
112\end{array}$ & $\begin{array}{l}4.5 \\
4.1 \\
4.1\end{array}$ & $\begin{array}{l}26 \\
38 \\
40 \\
70\end{array}$ & $\begin{array}{l}4.8 \\
6.0 \\
4.7 \\
2.5\end{array}$ & $\begin{array}{l}5.4 \\
5.4 \\
2.0 \\
1.9\end{array}$ & $\begin{array}{l}3.2 \\
3.9 \\
4.0 \\
1.9\end{array}$ & $\begin{array}{l}11.9 \\
14.4 \\
16.2 \\
15.6\end{array}$ & $\begin{array}{l}27.9 \\
34.2 \\
33.6 \\
24.4\end{array}$ & & \\
\hline $\begin{array}{l}\text { J. O. } \\
\text { Control for } \\
2-1-49\end{array}$ & $\begin{array}{l}\text { I } \\
\text { II } \\
\text { III } \\
\text { IV }\end{array}$ & $\begin{array}{c}120 \\
60^{*} \\
60^{*} \\
120\end{array}$ & & & & $\begin{array}{l}23.5 \\
46 \\
30 \\
24\end{array}$ & $\begin{array}{l}2.6 \\
6.9 \\
3.7 \\
3.0\end{array}$ & $\begin{array}{l}3.7 \\
7.4 \\
3.2 \\
2.0\end{array}$ & $\begin{array}{l}2.6 \\
4.8 \\
2.3 \\
2.1\end{array}$ & & & & \\
\hline
\end{tabular}

* Period of infusion.

TABLE VI

The effect of infusion of hypo- and iso-oncotic solutions of albumin on the concentrations of extracellular electrolytes, clearances, and rates of excretion of water and solutes in the urine

\begin{tabular}{|c|c|c|c|c|c|c|c|c|c|c|c|c|c|}
\hline \multirow{2}{*}{ Study } & \multirow{2}{*}{ Period } & \multirow{2}{*}{$\underset{\text { Dura- }}{\text { tion }}$} & \multicolumn{3}{|c|}{ Conc. in extracell. $\mathrm{H}_{2} \mathrm{O}$} & \multicolumn{6}{|c|}{ Rates of excretion in urine } & \multicolumn{2}{|c|}{ Clearances } \\
\hline & & & $\mathrm{Na}$ & $\mathrm{Cl}$ & $\mathbf{K}$ & $\mathrm{H}_{2} \mathrm{O}$ & $\mathrm{Na}$ & $\mathrm{Cl}$ & $\mathrm{K}$ & Urea & $\begin{array}{c}\text { Total } \\
\text { mOsm. }\end{array}$ & Creatin. & Urea \\
\hline $\begin{array}{c}\text { L. G. W. } \\
1-12-49 \\
4 \% \text { albumin } \\
\text { in saline }\end{array}$ & $\begin{array}{l}\text { I } \\
\text { II } \\
\text { III } \\
\text { IV }\end{array}$ & $\begin{array}{c}\min . \\
120 \\
60^{*} \\
60^{*} \\
120\end{array}$ & $\begin{array}{c}m E q / L \\
146 \\
\\
148 \\
150\end{array}$ & $\begin{array}{c}m E q / L \\
115 \\
121 \\
122\end{array}$ & $\begin{array}{c}m E q / L \\
4.4 \\
\\
4.4 \\
4.4\end{array}$ & $\begin{array}{l}c c . / 1^{\circ} \\
60.5 \\
220 \\
810 \\
208.5\end{array}$ & $\begin{array}{c}m E q / 1^{\circ} \\
10.3 \\
20.8 \\
41.4 \\
31.2\end{array}$ & $\begin{array}{c}m E q / 1^{\circ} \\
13.4 \\
22.9 \\
39.2 \\
33.7\end{array}$ & $\begin{array}{c}m E q / 1^{\circ} \\
4.2 \\
9.9 \\
10.4 \\
7.6\end{array}$ & $\begin{array}{c}m M / 1^{\circ} \\
15.0 \\
19.3 \\
17.0 \\
14.4\end{array}$ & $\begin{array}{r}m M / 1^{\circ} \\
44.0 \\
80.7 \\
120.6 \\
92.0\end{array}$ & $\begin{array}{c}c c . / \min . \\
122.1 \\
128 \\
124.5 \\
115.5\end{array}$ & $\begin{array}{c}c c . / \min . \\
49.2 \\
65.8 \\
58.1 \\
50.5\end{array}$ \\
\hline $\begin{array}{c}\text { L. G. W. } \\
2-17-49 \\
5 \% \text { albumin } \\
\text { in saline }\end{array}$ & $\begin{array}{l}\text { I } \\
\text { II } \\
\text { III } \\
\text { IV }\end{array}$ & $\begin{array}{c}120 \\
60^{*} \\
60^{*} \\
120\end{array}$ & $\begin{array}{l}147 \\
148 \\
149\end{array}$ & $\begin{array}{l}111 \\
115 \\
115\end{array}$ & $\begin{array}{l}4.6 \\
4.0 \\
4.3\end{array}$ & $\begin{array}{r}68 \\
241 \\
460 \\
200\end{array}$ & $\begin{array}{l}14.2 \\
17.0 \\
24.3 \\
20.3\end{array}$ & $\begin{array}{l}15.3 \\
17.3 \\
22.7 \\
21.6\end{array}$ & $\begin{array}{r}5.1 \\
9.9 \\
10.3 \\
7.3\end{array}$ & & & & \\
\hline $\begin{array}{c}\text { L. G. W. } \\
2-24-49 \\
6 \% \text { albumin } \\
\text { in saline }\end{array}$ & $\begin{array}{c}\text { I } \\
\text { III } \\
\text { IV }\end{array}$ & $\begin{array}{c}120 \\
60^{*} \\
60^{*} \\
120\end{array}$ & $\begin{array}{l}152 \\
151 \\
154\end{array}$ & $\begin{array}{l}112 \\
116 \\
118\end{array}$ & $\begin{array}{l}3.8 \\
3.9 \\
3.9\end{array}$ & $\begin{array}{l}50.5 \\
90 \\
\mathbf{5 7 0} \\
177.5\end{array}$ & $\begin{array}{l}10.9 \\
17.1 \\
30.9 \\
11.5\end{array}$ & $\begin{array}{l}13.8 \\
17.2 \\
24.2 \\
13.9\end{array}$ & $\begin{array}{l}4.1 \\
7.7 \\
9.6 \\
5.6\end{array}$ & & & & \\
\hline $\begin{array}{l}\text { L. G. W. } \\
\text { Control for } \\
4 \%, 5 \%, 6 \% \\
\text { albumin }\end{array}$ & $\begin{array}{l}\text { I } \\
\text { II } \\
\text { III } \\
\text { IV }\end{array}$ & $\begin{array}{c}120 \\
60^{*} \\
60^{*} \\
120\end{array}$ & & & & $\begin{array}{r}61 \\
220 \\
208 \\
282\end{array}$ & $\begin{array}{l}11.8 \\
22.5 \\
30.3 \\
49.6\end{array}$ & $\begin{array}{l}10.8 \\
22 \\
30.3 \\
54.8\end{array}$ & $\begin{array}{r}3.7 \\
5.6 \\
5.4 \\
10.2\end{array}$ & & & & \\
\hline $\begin{array}{c}\text { J. O. } \\
1-22-49 \\
4 \% \text { albumin } \\
\text { in } 5 \% \text { glucose }\end{array}$ & $\begin{array}{l}\text { I } \\
\text { II } \\
\text { III } \\
\text { IV }\end{array}$ & $\begin{array}{c}120 \\
60^{*} \\
60^{*} \\
120\end{array}$ & $\begin{array}{l}148 \\
142 \\
143 \\
146\end{array}$ & $\begin{array}{l}116 \\
109 \\
110 \\
112\end{array}$ & $\begin{array}{l}4.1 \\
3.5 \\
3.3 \\
4.1\end{array}$ & $\begin{array}{r}41 \\
145 \\
900 \\
300\end{array}$ & $\begin{array}{r}7.6 \\
10.3 \\
9.3 \\
10.5\end{array}$ & $\begin{array}{l}7.2 \\
9.0 \\
5.1 \\
9.1\end{array}$ & $\begin{array}{l}2.3 \\
3.7 \\
3.5 \\
2.5\end{array}$ & $\begin{array}{l}16.9 \\
22.2 \\
21.9 \\
17.5\end{array}$ & $\begin{array}{l}36.7 \\
50.2 \\
47.5 \\
43.5\end{array}$ & $\begin{array}{l}123 \\
121 \\
129.1 \\
110.5\end{array}$ & \\
\hline $\begin{array}{l}\text { J. O. } \\
\text { Control for } \\
1-22-49\end{array}$ & $\begin{array}{l}\text { I } \\
\text { II } \\
\text { III } \\
\text { IV }\end{array}$ & $\begin{array}{c}120 \\
60^{*} \\
60^{*} \\
120\end{array}$ & $\begin{array}{l}146 \\
138 \\
139 \\
141\end{array}$ & $\begin{array}{l}114 \\
111 \\
112 \\
112\end{array}$ & $\begin{array}{l}4.6 \\
4.1 \\
4.2 \\
4.2\end{array}$ & $\begin{array}{r}40 \\
45 \\
240 \\
173\end{array}$ & $\begin{array}{r}7.1 \\
7.4 \\
6.6 \\
11.7\end{array}$ & $\begin{array}{r}8.5 \\
8.6 \\
5.9 \\
12.6\end{array}$ & $\begin{array}{l}5.3 \\
5.9 \\
2.7 \\
4.0\end{array}$ & & & & \\
\hline
\end{tabular}

* Period of infusion.

Total volume of infusions-L. G. W.: 2,280 cc.; J. O.: 1,875 cc. 
TABLE VII

The effect of infusion of hypo-oncotic solutions of albumin on the concentrations of extracellular electrolytes, clearances, and rates of excretion of water and solutes in the urine under the influence of exogenous posterior pituitary hormone

\begin{tabular}{|c|c|c|c|c|c|c|c|c|c|c|c|c|}
\hline \multirow{2}{*}{ Study } & \multirow{2}{*}{ Period } & \multirow{2}{*}{$\begin{array}{c}\text { Dura- } \\
\text { tion }\end{array}$} & \multicolumn{3}{|c|}{ Conc. in extracell. $\mathrm{H}_{2} \mathrm{O}$} & \multicolumn{6}{|c|}{ Rates of excretion in urine } & \multirow{2}{*}{$\begin{array}{l}\text { Clearance } \\
\text { Creatinine }\end{array}$} \\
\hline & & & $\mathrm{Na}$ & $\mathrm{Cl}$ & $\mathbf{K}$ & $\mathrm{H}_{2} \mathrm{O}$ & $\mathrm{Na}$ & $\mathrm{Cl}$ & $\mathbf{K}$ & Urea & $\begin{array}{c}\text { Total } \\
\text { mOsm. }\end{array}$ & \\
\hline$\underset{6-5-50}{B .}$ & $\underset{\text { III }}{\text { II }}$ & $\begin{array}{c}\min . \\
119^{*} \\
54 \\
56\end{array}$ & $\begin{array}{c}m E q / L \\
142 \\
142\end{array}$ & $\begin{array}{c}m E q / L \\
117 \\
116\end{array}$ & $\begin{array}{c}m E_{Q} / L \\
4.0 \\
3.8\end{array}$ & $\begin{array}{r}c c . / 1^{\circ} \\
79.2 \\
53.3 \\
48.2\end{array}$ & $\begin{array}{c}m E q / 1^{\circ} \\
17.6 \\
12.2 \\
12.4\end{array}$ & $\begin{array}{c}m E q / 1^{\circ} \\
18.4 \\
12.3 \\
12.6\end{array}$ & $\begin{array}{c}m E q / 1^{\circ} \\
9.5 \\
4.6 \\
3.5\end{array}$ & $\begin{array}{c}m M / 1^{\circ} \\
20.9 \\
13.6 \\
12.5\end{array}$ & $\begin{array}{c}m M / 1^{\circ} \\
75.1 \\
67.2 \\
44.3\end{array}$ & $\begin{array}{l}c c . / \min . \\
105 \\
103 \\
85\end{array}$ \\
\hline $\begin{array}{c}\text { B. } \\
\text { Control for } \\
6-5-50\end{array}$ & $\begin{array}{c}\text { I } \\
\text { II }\end{array}$ & $\begin{array}{c}116 \dagger \\
60 \\
57\end{array}$ & & & & $\begin{array}{l}80.2 \\
65 \\
89.5\end{array}$ & $\begin{array}{l}18.4 \\
16.1 \\
24.1\end{array}$ & $\begin{array}{l}20.9 \\
17.2 \\
23.9\end{array}$ & $\begin{array}{l}8.3 \\
5.0 \\
4.5\end{array}$ & $\begin{array}{l}21.5 \\
16.6 \\
20.4\end{array}$ & $\begin{array}{l}74.9 \\
58.8 \\
77.6\end{array}$ & \\
\hline 6-5-50 & $\begin{array}{l}\text { II } \\
\text { III } \\
\text { IV }\end{array}$ & $\begin{array}{l}57^{*} \\
61^{*} \\
61 \\
55\end{array}$ & $\begin{array}{l}141 \\
141 \\
142\end{array}$ & $\begin{array}{l}116 \\
117 \\
117\end{array}$ & $\begin{array}{l}4.1 \\
3.9 \\
4.1\end{array}$ & $\begin{array}{c}65.2 \\
65.9 \\
56.0 \\
306\end{array}$ & $\begin{array}{l}11.8 \\
14.9 \\
14.7 \\
13.5\end{array}$ & $\begin{array}{l}11.7 \\
10.7 \\
12.5 \\
14.4\end{array}$ & $\begin{array}{l}9.7 \\
8.2 \\
4.9 \\
4.5\end{array}$ & $\begin{array}{l}12.8 \\
12.0 \\
13.1 \\
19.1\end{array}$ & $\begin{array}{l}55.8 \\
58.2 \\
52.3 \\
55.1\end{array}$ & $\begin{array}{c}99.2 \\
104 \\
99.6 \\
95.5\end{array}$ \\
\hline $\begin{array}{c}\text { S. } \\
\text { Control for } \\
6-5-50\end{array}$ & $\underset{\text { III }}{\text { II }}$ & $\begin{array}{l}61 \dagger \\
60 \dagger \\
65 \\
51\end{array}$ & & & & $\begin{array}{r}88.5 \\
95.0 \\
83.0 \\
241\end{array}$ & $\begin{array}{l}23.9 \\
31.4 \\
28.0 \\
26.5\end{array}$ & $\begin{array}{l}21.2 \\
26.9 \\
33.1 \\
26.8\end{array}$ & $\begin{array}{l}7.9 \\
6.6 \\
4.2 \\
4.9\end{array}$ & $\begin{array}{l}16.3 \\
16.6 \\
15.3 \\
18.9\end{array}$ & $\begin{array}{l}79.9 \\
90.6 \\
79.7 \\
81.7\end{array}$ & \\
\hline
\end{tabular}

* Period of infusion of $1,500 \mathrm{cc} .4 \%$ albumin in normal saline with 200 milli-units post. pituitary hormone.

$\dagger$ Period of infusion of $1,500 \mathrm{cc}$. normal saline with 200 milli-units post. pituitary hormone.

and the equivalent increase in filtration induced by lowering the colloid osmotic pressure of the plasma. The infusion necessary to reduce the colloid osmotic pressure, of course, also increased the volume of the plasma and interstitial fluid. The diuresis induced by dilution was 15 times as great as that induced by the equivalent change in capillary pressure. They concluded that the dilution promoted specific changes in renal tubular function resulting in a decreased reabsorption of water. Wilson and Harrison (5) studied the effects of rapid infusions of $900-1,955$ cc. of reconstituted human plasma in normal subjects. They observed an increase in the clearances of PAH and creatinine and a diuresis of water. The clearance of creatinine can hardly serve as a measure of the rate of glomerular filtration in this study since plasma levels were increased to $12-20 \mathrm{mgm} . \%$ by injection of this substance. Despite this, in three subjects to whom the infusions were administered more slowly (i.e., $22.5-30 \mathrm{cc}$. $/ \mathrm{min}$.) there was a diuresis of water in two with no alteration in the clearance of creatinine.

It is clear that the manner in which the volume of the plasma is increased and other more subtle variations may condition the response to this alteration in terms of the rates of excretion of water and electrolytes. In the present study there was a decrease in the rate of excretion of sodium, and sometimes water, in normal subjects when the plasma volume was expanded with concentrated solutions of albumin. These changes were not related to alterations in the rate of glomerular filtration as measured by the clearance of endogenous creatinine. An increase in the volume of the plasma achieved in this manner is, of course, associated with a contraction of the interstitial fluid volume and a rise in the colloid osmotic pressure of the plasma. In contrast to normal subjects, patients with the edema of the nephrotic syndrome (10-13) respond with increased rates of excretion of water and salt with this type of infusion despite the same changes in plasma volume, colloid osmotic pressure, and decrease in the volume of the interstitial fluid. There are, to be sure, quantitative differences in these alterations in the two groups. The volume of the interstitial fluid is contracted to an even greater extent and the increase in colloid osmotic pressure of the plasma is thereby mitigated in the edematous subjects. This is clearly demonstrated by comparing the increases in plasma volume expressed as cubic centimeters of plasma volume increase per gram of albumin infused in the two groups of subjects. The average increase was $20.6 \mathrm{cc}$. in the edematous patients (13), $13.2 \mathrm{cc}$. in the present study, and $9 \mathrm{cc}$. in the 
studies of Goodyer, Peterson, and Relman (17). Prior expansion of the extracellular volume with physiological saline in normal subjects did not modify the responses to infusions of hyperoncotic solutions of albumin; in these studies the average increase in plasma volume was $11.6 \mathrm{cc}$. per gm. of infused albumin. It seems unlikely, therefore, that the volume of the interstitial fluid per se influences the rates of excretion of sodium or water.

The question must be seriously raised as to whether a rise in plasma colloid osmotic pressure may be a stimulus for an increase in the reabsorption of salt and water by the renal tubules. Under ordinary circumstances an increase in the colloid osmotic pressure of the plasma is a reflection of dehydration associated with hemoconcentration. Greiner and Podhradszky (18) have suggested that a rise in plasma colloid pressure might activate the osmoreceptor mechanism of the supra-opticohypophyseal system. However, it is quite likely that the receptor organ for the posterior pituitary gland lies in an extravascular position. Moreover, if it were within the vascular tree it would be difficult to conceive that the minor contribution to a change in total osmotic pressure afforded by small variations in protein concentration could significantly influence this receptor. In addition, an antidiuresis does not always follow an infusion of a hyperoncotic solution of albumin, and when it does there is a reduction in the total milli-osmolar concentration of the urine. This is quite unlike what is observed with the antidiuresis promoted by the hormone of the posterior pituitary gland (19).

It is intriguing to speculate that a receptor organ lying within the vascular tree with the same characteristics of permeability as the endothelium could be specifically stimulated by the colloid (oncotic) pressure. Such an organ might be termed an onco-receptor. If the response to stimulation of such a mechanism were an increased reabsorption of sodium by the renal tubules, an increased reabsorption of water might follow as a consequence.

The retention of sodium and chloride associated with infusions of concentrated albumin appears not to be mediated through the action of the adrenal cortex. Subject R.N. is a patient with Addison's disease of 12 years' standing. He did not respond with an eosinopenia nor an increase in the excretion of 17 -ketosteroids in the urine following large doses of ACTH. An infusion of $25 \%$ albumin was associated with a distinct decrease in the rates of excretion of sodium and chloride in this patient (Table III).

There was no decrease in the rates of excretion of sodium associated with the infusion in normal subjects of hyperoncotic solutions of albumin in the evening studies (Table V). The rates of excretion of sodium and chloride in the control period were lower in the evening than in the morning studies, which is a reflection of the diurnal variation in mineral excretion $(20,21)$. There is, as yet, no valid explanation for the diurnal variation. However, this difference in response to an infusion of concentrated albumin at two different times of day emphasizes the importance of controlling this factor in studies involving the metabolism of electrolytes and water.

The increase in plasma volume associated with infusions of hypo- and iso-oncotic solutions of albumin promoted a striking augmentation in the rate of excretion of water with no essential change in the rates of excretion of sodium and chloride, when compared with the control studies. There is no evidence in these studies that this diuresis need be associated with an increase in the rate of glomerular filtration. Moreover, the diuresis of water was independent of the concentration of sodium in the serum and the rate of excretion of this ion. The fact that there was an antidiuresis following an infusion of a liter of $10 \%$ albumin militates against the possibility that the diuresis observed with hypo- and iso-oncotic solutions of albumin is due to a dilution of circulating posterior pituitary antidiuretic hormone. The lack of a diuresis associated with infusions of $25 \%$ and $10 \%$ solutions of albumin rejects the possibility that the albumin might inactivate pituitary antidiuretic hormone.

There remain two alternative explanations. An expansion of the plasma volume unassociated with any other measured alteration may be a direct stimulus for decreased reabsorption of water by the renal tubules, or it may, in some manner, suppress the production of antidiuretic hormone by the posterior pituitary gland. The absence of the usual diuretic response to an infusion of a hypo-oncotic solution of albumin when exogenous posterior pituitary hormone is incorporated in the infusate is compatible with the latter explanation. 
It may be possible to explain the different responses in the excretion of water and salt to infusions of hyperoncotic solutions of albumin in the normal subject and the patient with the nephrotic syndrome. The response to expansion of the plasma volume per se appears to be a diuresis of water. However, when the expansion of the plasma volume is achieved in the normal subject with a hyperoncotic solution of albumin, the diuresis of water is prevented, perhaps, by the associated increase in colloid osmotic pressure of the plasma which promotes an increased reabsorption of sodium, and consequently, water. In the nephrotic, on the other hand, the increase in plasma volume is greater, the rise in colloid osmotic pressure is thereby mitigated, and since tubular reabsorption of sodium is already nearly maximal, it can not be enhanced. Since tubular reabsorption of sodium can not be increased very much, the stimulus for water diuresis afforded by the expanded plasma volume is not inhibited.

In another investigation (13) it was demonstrated that the increase in the rate of excretion of sodium in the nephrotic associated with the infusion of a hyperoncotic solution of albumin occurred when the concentration of sodium in the extracellular water was increased as a consequence of the initial diuresis of water. The diuresis of water in the normal subject associated with infusion of an iso-oncotic solution of albumin is not followed by an increase in the rate of excretion of sodium. This may result from the fact that the large excretion of water causes an increase in the concentration of protein in the serum. This rise in colloid osmotic pressure promotes an increase in the tubular reabsorption of sodium and secondarily terminates the diuresis of water.

The present investigations are obviously inconclusive concerning the mechanisms responsible for the observed responses to infusions of hyper- and iso-oncotic solutions of albumin. Further work is in process in an attempt to define these mechanisms. The working hypotheses are that uncomplicated expansion of the plasma volume initiates a diuresis of water by suppressing the activity of the posterior pituitary gland, and that an acute increase in the colloid osmotic pressure of the plasma leads to an increase in renal tubular reabsorption of sodium through some unknown mechanism.

\section{SUMMARY AND CONCLUSIONS}

1. The intravenous administration of hyperoncotic solutions of albumin to normal human subjects in the morning results in a decreased rate of excretion of sodium and chloride which is sometimes associated with a decreased rate of excretion of water.

2. The decrease in rates of excretion of sodium and chloride is due, presumably, to an increase in renal tubular reabsorption of these ions, since there were no significant alterations in the clearance of endogenous creatinine. This increase in renal tubular reabsorption of salt is apparently not mediated via the adrenal cortex, since it was clearly observed in a subject with well validated Addison's disease.

3. The increase in plasma volume resulting from infusions of hyperoncotic solutions of albumin is derived from the interstitial fluid. However, the magnitude of the increase in plasma volume is not sufficient to prevent a significant increase in the concentration of albumin in the serum. The resultant increase in colloid osmotic pressure of the plasma may be the stimulus that promotes the increased reabsorption of sodium and chloride. An increase in oncotic pressure could be an effective stimulus if there were an onco-receptor which resided within the vascular tree.

4. These phenomena are not observed when the infusions of hyperoncotic solutions of albumin are administered in the evening. The differences between the morning and evening studies may be related to the diurnal variation in the rates of excretion of water and electrolytes. The modifying influence of the time of day on these experiments emphasizes the importance of considering the various circumstances that may condition a response with respect to the metabolism of electrolytes and water.

5. Experimentally induced expansion of the extracellular volume by approximately 2 liters does not modify the responses to the infusion of a hyperoncotic solution of albumin.

6. Infusion of iso- and hypo-oncotic solutions of albumin promotes a striking diuresis of water with no alteration in the rate of excretion of salt or clearance of endogenous creatinine. This diuresis appears to be due to a decreased reabsorption of water in the renal tubule. It is suggested 
that simple iso-oncotic expansion of the plasma volume suppresses the secretion of the posterior pituitary antidiuretic hormone.

\section{REFERENCES}

1. Knowlton, F. P., The influence of colloids on diuresis. J. Physiol., 1911, 43, 219.

2. Elkinton, J. R., Crosley, A. P., Jr., Barker, H. G., and Clark, J. K., Alterations in renal hemodynamics and excretion of electrolytes. Federation Proc., 1950, 9, 37.

3. Cargill, W. H., Effect of the intravenous administration of human serum albumin on renal function. Proc. Soc. Exper. Biol. \& Med., 1948, 68, 189.

4. Eggleton, M. G., Pappenheimer, J. R., and Winton, F. R., The mechanisms of dilution diuresis in the isolated kidney and the anesthetized dog. $J$. Physiol., 1940, 98, 336.

5. Wilson, J. R., and Harrison, C. R., Cardiovascular, renal, and general effects of large rapid plasma infusions in convalescent men. J. Clin. Invest., 1950, 29, 251.

6. Elkinton, J. R., and Taffel, M., Prolonged water deprivation in the dog. J. Clin. Invest., 1942, 21, 787.

7. Hald, P. M., The flame photometer for the measurement of sodium and potassium in biological materials. J. Biol. Chem., 1947, 167, 499.

8. Milne, J., Serum protein fractionation: A comparison of sodium sulfate precipitation and electrophoresis. J. Biol. Chem., 1947, 169, 595.

9. Elkinton, J. R., Danowski, T. S., and Winkler, A. W., Hemodynamic changes in salt depletion and in dehydration. J. Clin. Invest., 1946, 25, 120.

10. Luetscher, J. A., Jr., The effect of a single injection of concentrated human serum albumin on circulating proteins and proteinuria in nephrosis. J. Clin. Invest., 1944, 23, 365.
11. Thorn, G. W., Armstrong, S. H., Jr., Davenport, V. D., Woodruff, L. M., and Tyler, F. H., Chemical, clinical, and immunological studies on the products of human plasma fractionation. XXX. The use of salt-poor concentrated human serum albumin solution in the treatment of chronic Bright's disease. J. Clin. Invest., 1945, 24, 802.

12. Armstrong, S. H., Jr., Mechanisms of action of serum albumin therapy in internal medicine. Am. J. Med., 1948, 4, 390.

13. Orloff, J., Welt, L. G., and Stowe, L., The effects of concentrated salt-poor albumin on the metabolism and excretion of water and electrolytes in nephrosis and toxemia of pregnancy. J. Clin. Invest., 1950, 29, 770.

14. Podhradszky, L., The effect of isotonic and isooncotic solutions on kidney function. Orvosképzés, 1939, 29, 63.

15. Metcalf, W., The fate and effects of transfused serum or plasma in normal dogs. J. Clin. Invest., 1944, 23, 403.

16. Orloff, J., and Blake, W. D., Effects of concentrated salt-poor human albumin on metabolism and excretion of water and electrolytes in dogs. Am. J. Physiol., 1951, 164, 167.

17. Goodyer, A. V. N., Peterson, E. R., and Relman, A. S., Some effects of albumin infusions on renal function and electrolyte excretion in normal man. J. Appl. Physiol., 1949, 1, 671.

18. Greiner, A., and Podhradszky, L., Kidney function in diabetes insipidus. Lancet, 1947, 2, 498.

19. Verney, E. B., The antidiuretic hormone and the factors which determine its release. Proc. Roy. Soc., London, 1947, B 135, 25.

20. Simpson, G. E., Diurnal variations in the rate of urine excretion for two hour intervals: Some associated factors. J. Biol. Chem., 1924, 59, 107.

21. Manchester, R. C., The diurnal rhythm in water and mineral exchange. J. Clin. Invest., 1933, 12, 995. 